\title{
Khapra Beetle: A Review of Recent Control Methods
}

\author{
Usman Khalique ${ }^{1 *}$, Muhammad Umar Farooq ${ }^{1}$, Muhammad Faizan Ahmed ${ }^{2}$ and Umar Niaz ${ }^{1}$ \\ ${ }^{1}$ Department of Entomology, University of Agriculture, Faisalabad, Pakistan \\ ${ }^{2}$ Institute of Agricultural Sciences, PU, Lahore Pakistan
}

*Corresponding author: Usman Khalique, Department of Entomology, Pakistan

\begin{abstract}
Research work revealed that stored grain pests pose serious threats to stored food commodities and cause economic losses. Khapra beetle (Trogoderma granarium) considered one of the most destructive pests that has great economic importance because of starvation capability for three years and has best survival rate at low humidity. T. granarium cause heavy losses in stored commodities and decrease the quality and quantity of grains. Development of resistance in T. granarium against insecticides like malathion, phosphine and pyrethroids has further increased its economic importance. There is no review available in the literature for the stored products policy makers and managers to control this pest. Following study reveals the economic losses cause by Khapra beetle in storage structures and its control by using integrated pest management strategies
\end{abstract}

Keywords: Khapra beetle; Trogoderma granarium Everts; Economic losses; Integrated pest management

\section{Introduction}

The Trogoderma granarium Everts belongs to family Dermestidae and order Coleopteran and is a world's most destructive stored grain pest. 115 species of Trogoderma genus reported by [1] in the world out of which twelve (Table 1) are stored grain pests. In fact, T. granarium ranked as one of the 100 worst invasive species worldwide and has been recognized as an A2 quarantine organism [2]. Larval stage of this pest considered most destructive stage that causes heavy economic losses to stored grains and other food commodities. Depending upon temperature, complete development (egg to adult) occur from 26 to 220 days and $35^{\circ} \mathrm{C}$ is the optimum temperature for its best survival. For an impressive timeframe or if hatchlings are extremely swarmed, if temperature falls beneath $25^{\circ} \mathrm{C}$ they may enter diapause. In diapause conditions, hatchlings may stay for a long time in this condition [3].

Due to its continued occurrence on commodities status of $T$. granarium is of highly economic importance and become potential for spread by use of roll-on roll-off road transport and dry cargo containers that make it a potential threat to global food security. Regrettably, the pest is very common in granaries, godowns, bins, silos as well as farm houses in Pakistan. To ensure food safety and food security situation it is not only vital to control of this pest but is pre-requisite for export of cereal grains. Although, khapra beetle may control by routine treatments of stored grains for domestic species of stored grain pests and sufficiently avert significant economic losses. Development of resistance against conventional pesticides has posed a new challenge for the researchers. Prohibition was done by WTO Committee on SPS on importation of cereals, oilseed commodities and similar grains, seeds, meals and flours, thereof, to prevent the spread of this pest and to protect domestic production. This restriction is applicable to products consigned from Europe, Africa, Oceania and particularly the following Asian countries: Chinese, Afghanistan, Taipei, Iraq Cyprus, Iran, Israel, Korea, India Lebanon, Myanmar, Pakistan, Bangladesh Saudi Arabia, Sri Lanka, Turkey, Syria, and Yemen and other countries in which T. granarium 
has been reported. Such restrictions reinforced by facts that feeding by Khapra beetle larvae reduces quality of grain and weight loss. In Pakistan estimates of storage losses of food grains due to insects have been reported to vary widely; $4-10 \%$ [4], about 5.08\% [5], $5 \%$ [6], $3.5-25.5 \%$ [7]. Rahman et al. [8] reported average damage levels in India ranged from $6 \%$ to $33 \%$ of the grain in a single storage season, with maximum damage at $73 \%$. Wheat lost $24 \%$ of its viability and $2.6 \%$ of its weight at optimal conditions of $36^{\circ} \mathrm{C}$ and $15 \%$ infestation [9].

Table 1: Trogoderma species as stored grain pests.

\begin{tabular}{|c|c|c|}
\hline Order & Family & Species \\
\hline \multirow[t]{12}{*}{ Coleoptera } & Dermistidae & Trogoderma glabrum (Herbst,1783) \\
\hline & & Trogoderma versicolor (Creutzer, 1799) \\
\hline & & Trogoderma ornatum (Say, 1826) \\
\hline & & Trogoderma inclusum (LeConte, 1854) \\
\hline & & Trogoderma variable (Ballion, 1878) \\
\hline & & $\begin{array}{c}\text { Trogoderma sternale sternale (Jayne, } \\
\text { 1882) }\end{array}$ \\
\hline & & Trogoderma simplex (Jayne, 1882) \\
\hline & & Trogoderma granarium (Everts, 1898) \\
\hline & & $\begin{array}{l}\text { Trogoderma sternale plagifer (Casey, } \\
\text { 1916) }\end{array}$ \\
\hline & & $\begin{array}{l}\text { Trogoderma sternale maderae (Beal, } \\
\text { 1954) }\end{array}$ \\
\hline & & Trogoderma parabile (Beal, 1954) \\
\hline & & Trogoderma grassmani (Beal, 1954) \\
\hline
\end{tabular}

Treatment may result in less profit for wholesalers due to loss of grain. Severe infestations may make stored unpalatable or unmarketable. Due to depletion of specific nutrients, quality may decrease. In wheat, Sorghum and maize grains, there was a decrease in crude fat, sugars, total carbohydrates, protein nitrogen, starch contents, vitamins thiamin, riboflavin, niacin, total lipids, phospholipids, glycolipids, polar and non-polar lipids; increases in the levels of uric acid, moisture, crude fiber, total protein and anti-nutrient polyphenol were observed $[10,11]$. Trogoderma have assigned a pest status due to quality deteriorating characteristics as technical barrier to trade. Use of chemicals, botanicals and physical

Table 2: Control measures for Trogoderma granarium. strategies control the khapra beetle to some extent because they develop resistance against insecticides and botanicals and have best survival at low humidity and temperature. Biological control is effective against khapra beetle because naturel enemies only feed their host rather putting any damage to stored commodities.

As a stored grain pest Khapra Beetle T. granarium was first time reported from India in 1894 by Cotes. The latest literature reveals that the pest is present in more than 35 countries of the world [12]. This is a local pest of India yet favors hot and dry atmospheres of Asia, Africa and Eurasia [13] additionally reported in the USA $[14,15]$. It has achieved a status of extremely basic essential vermin of stored wheat, rice, and maize in the Indo-Pak subcontinent.

\section{Damage in Pakistan}

Agriculture area is the fundamental sector of Pakistan's economy that aides in Poverty Reduction Impact and gives crude materials to line industries. This division holds 21\% in Gross Domestic Product, and $42.3 \%$ of the nation's labor force involve in this sector. First schematic survey of losses was conducted by [5] in Pakistan and he reported that during post-harvest operations, 15.3\% aggregate losses of wheat occurs in the country. 10 to $15 \%$ post-harvest losses of grains in Pakistan observed by (Jilani, 1981), which were chiefly caused by attack of insect pests. Later, findings of (Ahmad and Afzal, 1984; AHMED, 1984) supported his report. In the same year, $22.7 \%$ post-harvest loss of wheat in Pakistan recorded by [3], out of which $13.2 \%$ during threshing and harvesting times while remaining 9.5\% occurred during storage period. On country wide basis, Irshad and Baloch [7] reported in Pakistan that storage losses of wheat ranged between 3.5 to $25 \%$. Losses of wheat grains stored for 4 months in go downs of Pakistan determined by TGM methods of loss assessment and Standard Volume Weight (SVW) are 2.03, 8.18 and $1.35 \%$ [16]. Average weight losses of $1.99,6.33$ and $2.01 \%$, respectively resulted in six months' wheat storage, while losses were recorded 3.02, 9.41 and $2.06 \%$ in 7 months storage period, determined by G.M. methods, T.G.M and S.V.W respectively [17]. Annual storage losses in public sector and at farm level recorded as 7 and $4 \%$ respectively [18]. Different control measures for Khapra beetle shown in Table 2 .

\begin{tabular}{|c|c|c|c|}
\hline Control & Treatments & Options & Remarks \\
\hline Chemical & Fumigation & Methyl bromide, Phosphene & Effective in small and large closed areas (Mueller, 1994). \\
\hline & Insecticides Dust & Malathion, pirimiphos-methyl & $\begin{array}{c}\text { Effective against all storage areas and their surroundings } \\
\text { (Pasek, 2004). }\end{array}$ \\
\hline Physical & $\mathrm{CO}_{2}$ & Any source of $\mathrm{CO}_{2}$ & $\begin{array}{c}100 \% \text { mortality was observed at }>60 \% \text { CO2 after 17-30 } \\
\text { days' exposure in small storage locallities. (YADAV and Mahla, } \\
\text { 2002). }\end{array}$ \\
\hline & $\mathrm{N}_{2}$ & Any source of $\mathrm{N}_{2}$ & $\begin{array}{c}\text { Larvae killed within 6 days of purging with N2 in small } \\
\text { storage areas. (Agboola, 2001). }\end{array}$ \\
\hline & Heat Treatment & Exposure to $60^{\circ} \mathrm{C}$ for 30 min & $100 \%$ kill of all stages (Burges, 2008). \\
\hline & Vacuuming & $\begin{array}{c}\text { Industrial vacuum conveying } \\
\text { system }\end{array}$ & $\begin{array}{c}99.6 \% \text { mortality after four passes through the system (Bahur, } \\
1990) .\end{array}$ \\
\hline
\end{tabular}




\begin{tabular}{|c|c|c|c|}
\hline Botanical & Botanicals & $\begin{array}{c}\text { Over 120 plants and plant products } \\
\text { including plethora, oras seed, garlic, } \\
\text { neem, lemon leaves, mint etc. }\end{array}$ & $\begin{array}{c}\text { Cheap and effective method for stored product pests. (Ali et } \\
\text { al., 2012). }\end{array}$ \\
\hline Biological & Pathogens & $\begin{array}{c}\text { Metarhizium anisopliae, } \\
\text { Bacillus thuringiensis, } \\
\text { Parasitic nematodes }\end{array}$ & $\begin{array}{c}\text { Mortality of pests in and around the storage areas. } \\
\text { (Khashaveh, 2011). }\end{array}$ \\
\hline & Parasatoid & ectoparasitoid Laelius pedatus & Control of Khapra Beetle in structures. (Rahman et al., 2009). \\
\hline & Predator & Xylocoris flavipes & $\begin{array}{r}\text { Control of Khapra Beetle in structures and surroundings } \\
\text { (Rahman et al., 2009). }\end{array}$ \\
\hline
\end{tabular}

\section{Chemical Control}

Chemical control and especially fumigation remain the first choice for the eradication of the khapra beetle. Methyl bromide, the most effective fumigant against stored products pests is scheduled to be phased out worldwide by 2015, according to Montreal Protocol, given that it is considered as a significant ozone-depleting substance. Currently, its application is restricted only for quarantine and pre-shipment uses (United Nations Environment Programme, 2010). A very promising strategy is the combination of a fumigant with $\mathrm{CO}_{2}$. Increased $\mathrm{CO}_{2}$ concentration accelerates respiration of the insects thereby making them more susceptible to fumigants. Recent and older studies have proved that addition of high levels of $\mathrm{CO}_{2}$ to phosphine resulted in significant additive effect and increased the mortality even against the most resistant stage of the khapra beetle, the diapausing larvae $[19,20]$.

Residual surface treatments with insect growth regulators, contact insecticides and aerosol applications have also been studied as an alternative for the control of T. granarium. Recent and older studies indicated that deltamethrin [21,22], fluvalinate [2], bifenthrin [23,24], fenvelerate [23-25], cypermethrin [23-25] chlorpyriphos-methyl [23,26,27], monocrotophos [23], mathacrifos [26], spinosad [28,29] and methoprene had shown potential for effective control of the khapra beetle based mainly on laboratory tests. On the other hand, malathion [22,26,27,30], pirimiphosmethyl [27], endosulfan and carbaryl [25] cannot always control T. granarium infestation. Irrespective of pest's susceptibility, in the case of surface treatments it should be taken into consideration that they are not always reliable not only because of the unique ability of larvae that diapause and hide in crevices and cracks for a long time but also because of the decreased insecticide persistence when applied on certain surfaces [31]. It is evident that there is a lack of very recent studies on this field. For the control of T. granarium, evaluation of aerosols and surface treatments are needed that has been emphasized in a recent review [32]. Combinations of the contact insecticides such as malathion and pirimiphos methyl with $\mathrm{N}_{2}$ - or $\mathrm{CO}_{2}$-modified atmospheres gave pronounced potentiation, demonstrating additive and antagonistic effects according to concentration and exposure time [30].

\section{Physical Control}

The phenomenon of resistance development by the khapra beetle to phosphine has forced the scientists to look for alternatives such as modified atmospheres, use of elevated temperatures and others, which had conventionally been used for many years in the past. Some of them are practically applied during the last 20 years, while some others are still under experimental. The potential use of $\mathrm{CO}_{2}$ atmosphere alone or in combination with heat as an alternative control method against T. granarium has also been demonstrated $[33,34]$. Diapausing larvae of the khapra beetle have been reported as the most tolerant stored product pest to a high- $\mathrm{CO}_{2}$ atmosphere, requiring very long exposure times for efficient control [35]. Complete mortality was observed at $>60 \% \mathrm{CO}_{2}$ after $17-30$ days exposure at $25-30^{\circ} \mathrm{C}[36,37]$. However, promising results have been derived when $\mathrm{CO}_{2}$ was combined with heat. An atmosphere composed of $90 \% \mathrm{CO}_{2}$ at $45^{\circ} \mathrm{C}$ reduces LT99 values for diapausing larvae of T. granarium from $29 \mathrm{~h}$ at $35^{\circ} \mathrm{C}$ to about $10 \mathrm{~h} \mathrm{[33],} \mathrm{whereas}$ LT95 was decreased to $<8 \mathrm{~h}$ [34]. That is why heat combined with a CO2-based modified atmosphere may be considered as one of the best alternatives to fumigants for treatment of storage pests [38]. N2-based atmospheres have also been used against the khapra beetle with promising results. Larvae were killed within 6 days of purging with N2 [39]. A novel 'vacuum-hermetic' technology has been developed recently (Finkelman et al., 2006). Developmental stages of T. granarium were exposed to low-pressure $(50 \mathrm{mmHg})$ within test chambers containing cocoa beans (R.H. $55 \%, 30^{\circ} \mathrm{C}$ ). Under those conditions, the most tolerant stage (egg) recorded complete mortality after $46 \mathrm{~h}$. Good quarantine solution can be provided by vacuum treatment under certain circumstances.

The use of low or freezing temperatures does not seem to be a feasible alternative method for the control of the khapra beetle. Although, populations of T. granarium have been shown to decline at $20^{\circ} \mathrm{C}$ and $70 \%$ R.H. [40], it is well documented that khapra beetle is major pest of stored products in cold-hardy [41-43]. Recent experiments have shown that $24-48 \mathrm{~h}$ is necessary for complete mortality even under 'unrealistic' freezing temperatures $\left(716^{\circ} \mathrm{C}\right)$ [43]. On the other hand, heat treatment has been well documented as an effective alternative against T. granarium [44-48]. Such methods may be practically applied mainly in countries where summer temperature exceeds $40^{\circ} \mathrm{C}$ and a little energy cost will incur to maintain temperature at $60^{\circ} \mathrm{C}$. Exposure of T. granarium to $60^{\circ} \mathrm{C}$ for $30 \mathrm{~min}$ is sufficient to achieve $100 \%$ kill of all stages [40]. Moreover, when pupae were exposed to $45^{\circ} \mathrm{C}$ for $48 \mathrm{~h}$ the emerging adults were sterile [41]. There are not many data concerning the effectiveness of inert dusts against the khapra beetle. When several 
types of inert dusts (DE, silico phosphates etc.) were evaluated against the major stored grain pests, they were somewhat less effective for khapra beetle larvae [49-52].

The combined action of DE and modified atmospheres of $\mathrm{CO} 2$ and N2 produced enhanced mortalities than each method separately against larvae and adults of T. granarium, indicating synergistic or additive effect [52]. Complete control of all stages of T. granarium has been also achieved when infested grain was pneumatically conveyed, ranking the pest among the most susceptible stored products pests. Conveying of wheat through an industrial vacuum conveying system gave $99.6 \%$ mortality after four passes through the system [53]. Gamma or other types of irradiation have also been evaluated as a quarantine treatment against the khapra beetle [5457]. Radioisotopes such as electron beam accelerators and cobalt 60 gamma radiations can be used to disinfest stored grain products. Apart from gamma, UVC irradiation has also been evaluated as a control agent against the khapra beetle. Eggs and pupae were the most sensitive and tolerant stages, respectively [56]. Despite the rapid mortality caused by irradiation, certain limitations of the method (low acceptance from the consumers, not approved for use in storages in many countries etc.) are preventing the spread of its practical application in more countries. Currently, several stored grains and pulses are commercially irradiated in Indonesia, France, and South Africa. It is certainly a very promising quarantine treatment.

\section{Plant Extracts (Botanicals)}

The most extensive research on control methods against the khapra beetle that has been carried out during the last 10 years deals with the use of plant extracts (essential oils, botanical powders etc.). Repellence toxicity of a plethora of plant species against $T$. granarium have been evaluated [58-65]. Characteristically, the use of neem (Azadirachta indica) essential oil as a fumigant and oras seed powder seemed to be a cheap and effective method to manage insect pest especially in developing countries [63]. Despite the promising results, plant oils and powders remain mainly experimental because of certain limitations with their production, quality standardization, formulation, and commercialization.

\section{Biological Control}

Many natural enemies (predator's parasitoids, nematodes, pathogens etc.) have also been studied as control agents against the khapra beetle. The entomopathogens Mattesia trogodermae Canning (Protozoa: Neogregarinida) [66], Metarhizium anisopliae (Metschinkoff) (Ascomycota: Hypocreales) [67], Bacillus thuringiensis Berliner (Bacilli: Bacillaceae) [68,69] (Rhabditida: Steinernematidae), [70] the Laelius pedatus (Say) ectoparasitoid (Hymenoptera: Bethylidae) and the generalist Xylocoris flavipes (Reuter) predator (Hemiptera: Anthocoridae) Rahman et al. [71] have been found to parasitize or prey on the khapra beetle.

\section{Conclusion}

From the above study, 120 plants, their products and different chemicals have been used to control stored product pests [72]. Due to threat of insecticide resistance development in them, integrated pest management (IPM) practices should be followed. Chemicals, botanicals [73-79], physical and biological control measures should be used in a compatible manner to manage stored product pests below their infestation level and minimize the chances of resistance development in them [80].

\section{References}

1. Beal RS (1954) Biology and taxonomy of the Nearctic species of Trogoderma (Coleoptera: Dermestidae). Biology and taxonomy of the nearctic species of Trogoderma (Coleoptera: Dermestidae) 10: 35-102.

2. Lowe S, M Browne, S Boudjelas, M De Poorter (2000) 100 of the world's worst invasive alien species: a selection from the global invasive species database.

3. Ahmad SI, M Afzal (1984) Harvest and post-harvest losses in wheat, Prog Farm pp. 31-35.

4. Haque H, M Anwar, A Begum (1969) Control of the Khapra beetle in larval stage by use of malathion. Agr Pakistan.

5. Chaudhry M (1980) Aggregate post-harvest food grain losses in Pakistan. Vol. VI., Dept. Agric. Mart., Univ. Agric., Faisalabad, Pakistan, pp. 66.

6. AHMED H (1984) Losses incurred in stored food grains by insects. A review. PARC Grain Storage Res. Lab. Kar 4(3): 198-207.

7. Irshad M, U Baloch (1985) Losses in wheat during storage and their prevention. Progressive Farming (Pakistan).

8. Rahman KA, G Sohi, A Sapra (1945) Studies on stored grain pests in the Punjab. VI. Biology of Trogoderma granarium Everts. Indian J Agric Sci 15: 85-92.

9. Prasad H, P Bhatia, G Sethi (1977) Estimation of feeding losses by Trogoderma granarium Everts in wheat. Indian Journal of Entomology 39: 377-378.

10. Jood S, AC Kapoor, R Singh (1995) Polyphenol and phytic acid contents of cereal grains as affected by insect infestation. Journal of agricultural and food chemistry 43(2): 435-438.

11. Jood S, AC Kapoor, R Singh (1996) Effect of insect infestation and storage on lipids of cereal grains. Journal of agricultural and food chemistry 44(6): 1502-1506.

12. Pasek JE (2004) USDA Pest Risk Assessment: Khapra Beetle. USDA APHIS, Center for Plant Health Science and Technology Raleigh Plant Protection Center.

13. Burges H (1959) Studies on the Dermestid Beetle Trogoderma granarium Everts: Ecology in Malt Stores. Annals of Applied Biology 47(3): 445-462.

14. Jensen DD (1954) Proceedings of the Pacific Coast Entomol. Soci PanPacific Entomol 30: 77-91.

15. Lindgren D, L Vincent, H Krohne (1955) The khapra beetle, Trogoderma granarium Everts. California Agriculture 24: 1-36.

16. Mohammad R (1986) Assessment of Storage losses of wheat grains in the food Deptt. M.Sc. (Hons), NWFP Agric Univ Peshawar.

17. Khan I (1986) Assessment of wheat grains losses occurring in various types of food department stores at Peshawar (NWFP) Pakistan.

18. Baloch UK (1986) Post harvest research in food grains. Pak. Agric. Res. Council, Pakistan. 
19. Desmarchelier J, R Wohlgemuth (1984) Response of several species of insects to mixtures of phosphine and carbon dioxide, Controlled Atmosphere and Fumigation in Grain Storages. Elsevier Amsterdam pp. 75-81.

20. El Lakwah FA, R Wohlgemuth, M Khattab (1989) Efficiency of phosphine and combinations of phosphine with carbon dioxide against Khapra Beetle larvae Trogoderma granarium everts. (Col., Dermestidae). Anzeiger für Schädlingskunde 62: 85-88.

21. Yadav $\mathrm{T}$ (1987) Toxicity of deltamethrin, cypermethrin, permethrin against thirteen stored product insects. Indian J Entomol 49: 21-26.

22. Farooq A, MD Gogi, H Mansoor (2000) Relative efficacy of different grain protectants against various strains of Trogoderma granarium Everts. Pak Entomol 22: 55-57.

23. Dwivedi S, R Kumar (1997) Effects of synthetic pyrethroids and organophosphates on hatching of beetle Trogoderma granarium. J Ecotoxicol Environ Monit 7: 67-69.

24. Reddy Y, SG Swamy (2006) Bioefficacy of bifenthrin as a prophylactic against four major stored grain pests. Resistant Pest Management Newsletter 16: 16-18.

25. Khosla R, B Chhillar, R Kashyap (2005) Efficacy of insecticidal dusts on natural infestation of Trogoderma granarium (Everts) on wheat seeds. Annals of Biology (India) 21(1): 69-72

26. Aheer G, M Ulfat, A Ali (1991) Grain protectants performance against insect pests of stored grain. Journal of Agricultural Research Pakistan.

27. Ahmad M, T Mahmood (1992) Mechanical filling and protection of wheat in hexagonal bins with reldan (Chlorpyrifos-methyl) and actellic (Primiphos-methyl). Pakistan Journal of Zoology 24: 95-95.

28. Fang L, B Subramanyam, FH Arthur (2002) Effectiveness of spinosad on four classes of wheat against five stored-product insects. Journal of Economic Entomology 95: 640-650.

29. Toews MD, B Subramanyam (2003) Contribution of contact toxicity and wheat condition to mortality of stored-product insects exposed to spinosad. Pest management science 59(5): 538-544.

30. El Laqwa FA, MM Azab, HA El Qadhi (2006) Efficiency of certain insecticides under modified atmospheres against some stored product insects. Annals of Agricultural Science Moshtohor.

31. Obretenchev A, E Stancheva, D Obretenchev (2007) Persistence of some organophosphorus insecticides applied on different surfaces and packages to the adult insect of Trogoderma Granarium Everts (Coleoptera: Dermestidae). Plant Science.

32. Arthur FH (2012) Aerosols and contact insecticides as alternatives to methyl bromide in flour mills, food production facilities, and food warehouses. Journal of pest science 85: 323-329.

33. Navarro S, S Finkelman, E Donahaye, R Dias, M Rindner, et al. (2002) Integrated storage pest control methods using vacuum or $\mathrm{CO} 2$ in transportable systems. Iobc Wprs Bulletin 25: 207-214.

34. Navarro S, S Finkelman, G Sabio, A Isikber, R Dias, et al. (2003) Enhanced effectiveness of vacuum or $\mathrm{CO} 2$ in combination with increased temperatures for control of storage insects, In, Proceedings of 8th International Working Conference on Stored-Product Protection (York.) CAB Int Oxon, Wallingford. pp. 818-822.

35. Annis P (1986) Towards rational controlled atmosphere dosage schedules: a review of current knowledge, pp. 128-148. In, Proceedings of the Fourth International Working Conference on Stored-Product Protection, Tel Aviv, Israel, Pakistan.

36. Spratt E, G Dignan, H Banks (1985) The effects of high concentrations of carbon dioxide in air on Trogoderma granarium Everts (Coleoptera: Dermestidae). Journal of stored products research 21(1): 41-46.

37. Yadav S, J Mahla (2002) Bioefficacy of carbondioxide concentration and its exposure against khapra beetle, Trogoderma granarlumin wheat grain. Indian journal of entomology 64: 130-137.
38. Bera A, S Sinha, N Singhal, R Pal, C Srivastava (2004) Studies on carbon dioxide as wheat seed protectant against storage insects and its effect on seed quality stored under ambient conditions. Seed science and Technology 32(1): 159-169.

39. Agboola SD (2001) Current status of the controlled atmosphere storage in Nigeria. Journal of Food Technology in Africa 6(1): 30-36.

40. Burges H (2008) Development of the khapra beetle, Trogoderma granarium, in the lower part of its temperature range. Journal of stored products research 44(1): 32-35.

41. Fields PG (1992) The control of stored-product insects and mites with extreme temperatures. Journal of Stored Products Research 28(2): 89118.

42. Dohino T, S Masaki, I Matsuoka, M Tanno, T Takano (1999) Low temperature as an alternative to fumigation for disinfesting stored products. Research Bulletin of the Plant Protection Service, Japan.

43. Eliopoulos PA, GZ Prasodimou, AV Pouliou (2011) Time-mortality relationships of larvae and adults of grain beetles exposed to extreme cold. Crop Protection 30: 1097-1102.

44. Mookherjee P, M Jotwani, T Yadav, P Sircar (1968) Disinfestation of stored seeds by heat treatment. Indian J Ent 30: 197-202.

45. Battu G, S Bains, A Atwal (1975) lethal effect of high temperature on the survival of the larvae of Trogoderma granarium Everts. Indian journal of ecology.

46. Ismail A, S Abid, N Mawlood (1988) Effect of high temperature on the mortality of the red flour beetle Tribolium confusum and khapra beetle Trogoderma granarium. Zanco 1: 35-42.

47. Taheri M (1988) Effect of various degrees of temperatures on different stages of Trogoderma granarium. Entomologie et Phytopathologie Appliquees (Iran)

48. Saxena B, P Sharma, R Thappa, K Tikku (1992) Temperature induced sterilization for control of three stored grain beetles. Journal of Stored Products Research 28: 67-70.

49. Singh K, H Bhavnagary, S Majumder (1984) Silicophosphate as new insecticide. I. Evaluation of silicophosphates for the control of stored grain pests in milled rice. Journal of food science and technology 21 302-307.

50. Bhavnagary H, K Singh, S Majumder (1988) Silicophosphates as new seed protectents: studies on the damage by Trogoderma granarium Everts and its effect on the germination of wheat seeds treated with silicophosphates. Seed science and technology (Switzerland).

51. Quarles W, P Winn (1996) Diatomaceous earth and stored product pests. IPM practitioner 18: 1-10

52. El Lakwah F, M Gharib (2005) Efficacy of diatomaceous earth dust under modified atmospheres against some stored grain insects. Annals of Agricultural Science, Moshtohor.

53. Bahr I (1990) Reduction of stored product insects during pneumatic undloading of ship cargoes. In, 5. International working conference on stored-product protection, Bordeaux (France), pp. 9-14.

54. Abdel Kawy F (1999) Effect of gamma-irradiation on some biological activities of the larval stage of the khapra beetle, Trogoderma granarium Everts (Col., Dermestidae). Journal of Applied Entomology 123(4): 201204.

55. Arthur V, LCAS Silva (2007) Control of Trogoderma granarium through of gamma radiation of cobalt-60. In, International Nuclear Atlantic Conference.

56. Ghanem I, M Shamma (2007) Effect of non-ionizing radiation (UVC) on the development of Trogoderma granarium Everts. Journal of stored products research 43(4): 362-366.

57. Abdel Kader MH, AM El Nozahy, SM Ahmed, IA Khalifa, LM El Nadi (j2007) Biochemical studies of the effect of two laser radiation wavelengths 
on the khapra beetle Trogoderma granarium Everts. (Coleoptera: Dermestidae), In, AIP Conference Proceedings, AIP. pp. 225-230.

58. Arivudainambi N, R Singh (2003) Fumigant toxicity of Neem (Azadirachta indica A. Juss.) seed oil volatiles against khapra beetle, Trogoderma granarium. Annals of Plant Protection Sciences 11: 207-211.

59. Cis J, G Nowak, W Kisiel (2006) Antifeedant properties and chemotaxonomic implications of sesquiterpene lactones and syringin from Rhaponticum pulchrum. Biochemical systematics and ecology 34(12): 862-867.

60. Khalif J, I Al Farhani (2008) Effect of some plants powder comparative in preference of Khapra Beetle Trogoderma granarium Everts Coleoptera: Dermestidae. Basra J Agric Sci 21: 70-93.

61. Egwurube E, B Magaji, Z Lawal (2010) Laboratory evaluation of neem (Azadirachta indica) seed and leaf powders for the control of khapra beetle, Trogoderma granarium (Coleoptera: Dermestidae) infesting groundnut. International Journal of Agriculture and Biology 12: 638640.

62. Bounechada M, M Fenni, F Benia (2011) Survey of Insects Pest Stored and Biological Control of Trogoderma Granarium Everts in Setifian Region (North-East of Algeria). Bulletin UASVM Agriculture 68: 1.

63. Ali A, F Ahmad, A Biondi, Y Wang, N Desneux (2012) Potential for using Datura alba leaf extracts against two major stored grain pests, the khapra beetle Trogoderma granarium and the rice weevil Sitophillus oryzae. Journal of Pest Science 85(3): 359-366.

64. Omar K, NM Faraj, SA Malik, IM Al Farhani (2012) Effect of some medicinal plants extracts and cypermthrin against Khapra Beetle (Trogoderma granarium Everts). Emirates Journal of Food and Agriculture 24(2): 120.

65. Tayoub G, A Abu Alnaser, I Ghanem (2012) Fumigant activity of leaf essential oil from Myrtus communis L. against the khapra beetle. International Journal of Medicinal and Aromatic Plants 2(1): 207-213.

66. Henri (1981) United States-khapra beetle infestations, FAO Plant Protec. pp. 29-30.

67. Khashaveh A (2011) Pathogenicity of Iranian isolates of Metarhizium anisopliae (Metschinkoff) (Ascomycota: Hypocreales) against
Trogoderma granarium Everts (Coleoptera: Dermestidae). Biharean Biologist 5(1):51-55.

68. Khaliq MSAA, M Haque (2007) Scope of commercial formulations of Bacillus thuringiensis Berliner as an alternative to methyl bromide against Trogoderma granarium Everts larvae. Pak J Bot 39: 871-880.

69. Ali S, A Shaheen, M Asif, M Akhtar (2009) Steinernema qazii sp. n.(Nematoda: Rhabditidae: Steinernematidae) from Kanpur, India. Trends in Biosciences 2(1): 59-64.

70. Eliopoulos P (2013) New approaches for tackling the khapra beetle. CAB Int Rev 8: 1-13.

71. Rahman M, W Islam, K Ahmed (2009) Functional response of the predator Xylocoris flavipes to three stored product insect pests. Int J Agric Biol 11: 316-320.

72. Dales M (1996) A review of plant materials used for controlling insect pests of stored products, NRI.

73. Casey TL (1916) Some random studies among the Clavicornia. Memoirs on the Coleoptera 7: 35-292.

74. Finkelman S, S Navarro, M Rindner, R Dias (2006) Effect of low pressure on the survival of Trogoderma granarium Everts, Lasioderma serricorne (F.) and Oryzaephilus surinamensis (L.) at 30 C. Journal of stored products research 42(1): 23-30.

75. Herbst JFH (1783) Natural system of all known domestic and foreign insects.

76. Jayne HF (1882) Revision of the Dermestid œ of the United States. Proceedings of the American Philosophical Society pp. 343-377.

77. Jilani G (1981) Post harvest protection of food grains with natural insect repellents. Progressive Farming.

78. LeConte JL (1854) Synopsis of the Dermestidae of the United States.

79. Mueller DK (1994) A new method of using low levels of phosphine in combination with heat and carbon dioxide. Fumigants and pheromones 33: 1-4.

80. Say $\mathrm{T}$ (1826) Descriptions of new species of coleopterous insects inhabiting the United States. Acad Natl Sci Phil J 5: 237-284.

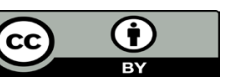

This work is licensed under Creative Commons Attribution 4.0 License

To Submit Your Article Click Here: Submit Article

DOI: $10.32474 /$ CIACR.2018.05.000222

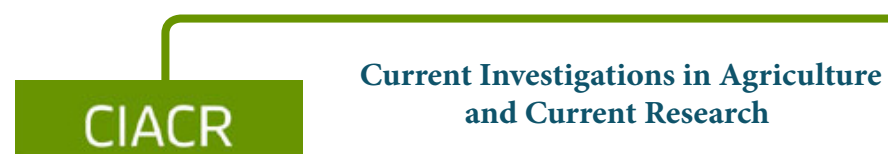

Assets of Publishing with us

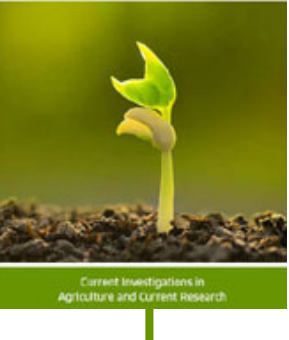

- Global archiving of articles

- Immediate, unrestricted online access

- Rigorous Peer Review Process

- Authors Retain Copyrights

- Unique DOI for all articles 